F. Reprod. Fert. (1972) 28, 191-196

\title{
SECRETION RATES OF OESTROGENS INTO THE OVARIAN VENOUS BLOOD OF PREGNANT RATS
}

\author{
H. B. WAYNFORTH, ${ }^{*}$ G. S. POPE AND ZENA D. HOSKING \\ *Courtauld Institute of Biochemistry, Middlesex Hospital Medical School, \\ London, W1P 5PR, and National Institute for Research in Dairying, \\ Shinfield, Reading RG2 $9 A T$
}

(Received 12th Fanuary 1971)

\begin{abstract}
Summary. The secretion rates of oestradiol-17 $\beta$ and oestrone into the ovarian venous blood of rats on the day of pro-oestrus and on nine different occasions in pregnancy have been measured by collection of blood samples and assay of extracts by the intravaginal, tetrazoliumreduction method in mice.

Secretion rate of oestradiol-17 $\beta$ at pro-oestrus and 1 to 2 days before parturition was about $3 \mathrm{ng} / \mathrm{ovary} / \mathrm{hr}$ but was much lower at other times in pregnancy. There was a significant rise in oestradiol-17 $\beta$ secretion rate from the 3 rd to the 4 th day post coitum ( 81 to $500 \mathrm{pg} / \mathrm{ovary} / \mathrm{hr}$ ).

Secretion rates of oestrone were always less than $300 \mathrm{pg} / \mathrm{ovary} / \mathrm{hr}$ and did not show marked rises at pro-oestrus and before parturition.

The physiological significance of the changes in ovarian oestrogen secretion rate is discussed.
\end{abstract}

\section{INTRODUGTION}

In pregnant rats, oestrogen is thought to be mainly, or entirely, of corpus luteum origin (Alloiteau \& Mayer, 1967). Thus, a knowledge of ovarian secretion rates may be expected to provide information on the rôle of oestrogen in the control of the events of pregnancy in this species. A series of estimates of oestrogen secretion into ovarian venous blood has therefore been made.

\section{MATERIALS AND METHODS}

\section{Animals}

Ovarian venous blood samples, one sample per animal, were taken from closed-colony Wistar rats. Midnight preceding the time of finding spermatozoa in the vaginal smear was taken as the time of coitus and as zero time in pregnancy.

Adult Porton-strain mice, ovariectomized 8 days previously, were used for oestrogen bioassay.

\section{Blood samples}

Ovarian venous samples from anaesthetized rats were collected over a period 
of $30 \mathrm{~min}$ into ice-cooled, polyethylene tubes by cannulation of the left renal vein after appropriate ligation and administration of heparin by way of the sublingual vein (Ganguly, Pope, Thompson, Toothill, Edwards-Webb \& Waynforth, 1971).

Samples were collected in this way from a group of rats (six to eighteen, usually ten), one after the other, during a single day (10.00 to 18.00 hours), all rats in the group being at the same day of pregnancy. Such collections were made from rats on 9 different days of pregnancy and from pro-oestrous rats. Second collections from similar rats were made at most of the times in pregnancy chosen for study, followed in some instances by third collections. Samples were stored at $-20^{\circ} \mathrm{C}$.

\section{Radioactive oestrogens used as tracers}

Tritium-labelled oestradiol- $17 \beta$ and oestrone, each labelled in the 2,4,6 and 7-positions (nominal) and of specific activity $100 \mathrm{Ci} / \mathrm{mmol}$, were obtained from the Radiochemical Centre, Amersham (batches TRK 322 and TRK 321, respectively). They were stored at $4^{\circ} \mathrm{C}$ (dark) in toluene solution when loss of radiochemical purity (as assessed by thin-layer chromatography) was 2 to $3 \%$ per month. Corrections for this were made when calculating percentage oestrogen recovery from blood samples.

Radioactivity determinations were made by the liquid-scintillation method.

\section{Extraction procedure}

Extraction of oestrogens from the blood and preparation of the oestrogenic extracts for assay were accomplished by a sequence of well known methods.

(1) Blood samples, collected on the same day from a group of rats at the same stage of pregnancy, were together added to 10 vol. acetone containing $\left[{ }^{3} \mathrm{H}\right]$ oestradiol- $17 \beta$ and $\left[{ }^{3} \mathrm{H}\right]$ oestrone $(60 \mathrm{pg} ; 40,000 \mathrm{~d} / \mathrm{min}$ approx. of each). The mixture was left overnight $\left(20^{\circ} \mathrm{C}\right.$, dark $)$ then filtered and the solvent evaporated.

(2) The extract from (1) was partitioned between ether and aqueous $1 \%$ $\mathrm{NaHCO}_{3}$ in order to separate from water-soluble derivatives (conjugates) of oestrogens. In some preliminary experiments, the $\mathrm{NaHCO}_{3}$ phase was neutralized and submitted to acid hydrolysis but no liberated oestrogen was detected; this phase was not further investigated. The ether phase yielded an extract (about $100 \mathrm{mg}$ ) which was chromatographed on a 3-g column of silica gel (chromatographic adsorption grade, 60 to 120 mesh-BDH Chemicals Ltd) packed using light petroleum. Elution with toluene and acetone gave fat and oestrogen-containing fractions, respectively.

(3) Phenolic matter (about $5 \mathrm{mg}$ ) was then isolated from the oestrogencontaining fraction (about $20 \mathrm{mg}$ ) (Brown, 1955).

(4) This phenolic matter was submitted to chromatography (Storry \& Tuckley, 1967) on 0.5-mm layers of Kieselgel GF 254 (E. Merck A.G.) and fractions having the chromatographic mobility of oestradiol-17 $\beta$ and oestrone were recovered.

(5) The oestradiol-17 $\beta$ and oestrone-containing fractions were then partitioned between aqueous methanol and light petroleum and again recovered by 
evaporation of the aqueous methanol phases. They were then each dissolved in $100 \mu \mathrm{l}$ of $10 \%$ propane-1,2-diol in water (v/v) for bioassay.

\section{Estimation of oestrogen recovery}

Checks of recovery of added $\left[{ }^{3} \mathrm{H}\right]$ oestradiol- $17 \beta$ and $\left[{ }^{3} \mathrm{H}\right]$ oestrone were made on five occasions during the extraction procedure, one of these being on a portion of the $10 \%$ propane-1,2-diol solution $2 \mathrm{hr}$ before its use in the bioassay.

\section{Oestrogen assay}

The oestradiol-17 $\beta$ and oestrone-containing fractions in $10 \%$ propane-1,2diol were assayed by the mouse intravaginal, tetrazolium-reduction method (Martin, 1960, 1964). For oestradiol-17 $\beta,(2,2)$ parallel-line assays were done; for oestrone, which was found in the blood at lower levels, only $(2,1)$ assays, i.e. one level without dilution of unknown, were practicable. Standard doses of oestradiol-17 $\beta$ were 7 and $42 \mathrm{pg} /$ mouse and of oestrone were 38 and 228 $\mathrm{pg} / \mathrm{mouse}$, ancillary work having indicated linearity of dose-response relationships in these regions.

In all assays, five mice were used at each dose level. The responses to increased dose showed marked increase in variability as their mean values increased and a logarithmic transformation was used to stabilize the variance. Assays (of oestradiol-17 $\beta$ or oestrone from each of the group collections at a particular day of pregnancy) were analysed individually and then results relating to blood taken at the same day of pregnancy were combined (Finney, 1964). Results were interpreted on the basis that the biological activity of the oestradiol-17 $\beta$ and oestrone-containing fractions from the blood samples was entirely due to oestradiol- $17 \beta$ and oestrone, respectively.

The reliability of the procedure was investigated by testing samples of systemic blood from ovariectomized rats of about the same sample volume (20 to $25 \mathrm{ml}$ ) as the pooled ovarian samples from the pregnant rats.

To each of two such systemic samples ( 23 and $26 \mathrm{ml}$ ), $1 \mathrm{ng}$ oestradiol-17 $\beta$ was added in addition to the $\left[{ }^{3} \mathrm{H}\right]$ oestradiol- $17 \beta$ tracer $(60 \mathrm{pg})$ and, after assay, the combined estimate (with $95 \%$ confidence limits) of oestradiol-17 $\beta$ per sample was $0.91(0.35$ and 2.6$) \mathrm{ng}$. To a third systemic sample $(25 \mathrm{ml})$, tracer only was added and the mean response in the assay (optical extinction at $490 \mathrm{~nm}$ ) was 0.083 which did not differ significantly from that of 0.087 for mice receiving $10 \%$ propane-1,2-diol only. These results may be compared with the combined estimate of $0.43(0.25$ and 0.69$) \mathrm{ng}$ oestradiol- $17 \beta / 2 \mathrm{ml}$ pool, for two pools of ovarian venous blood (22 and $22 \mathrm{ml}$ ) collected on the 3rd day post coitum when oestradiol-17 $\beta$ levels in pregnancy were lowest (Text-fig. 1). Thus, there is no evidence of non-specific response from extracts of rat blood.

\section{RESULTS}

In Text-fig. 1, ovarian secretion rates of oestradiol-17 $\beta$ and oestrone at various times in pregnancy are shown, together with the values on the day of prooestrus. A significant rise in oestradiol-17 $\beta$ secretion (from 81 to $500 \mathrm{pg} / \mathrm{ovary} /$ hr), but not in that of oestrone, took place from the 3 rd to the 4 th day. Secretion 
rate of oestradiol-17 $\beta$ then fluctuated at about this upper level until the 17th day with an indication of a lowered level at about the 12th day. On the 22nd day (within 1 to 2 days of parturition), it was very much greater $(2.6 \mathrm{ng} / \mathrm{ovary} /$ $\mathrm{hr}$ ) and approached that found on the day of pro-oestrus (3.3 $\mathrm{ng} / \mathrm{ovary} / \mathrm{hr}$ ). Ovarian oestrone secretion rates were generally low relative to those of oestradiol-17 $\beta$; there was no very marked rise in oestrone secretion rate at pro-oestrus or before parturition.

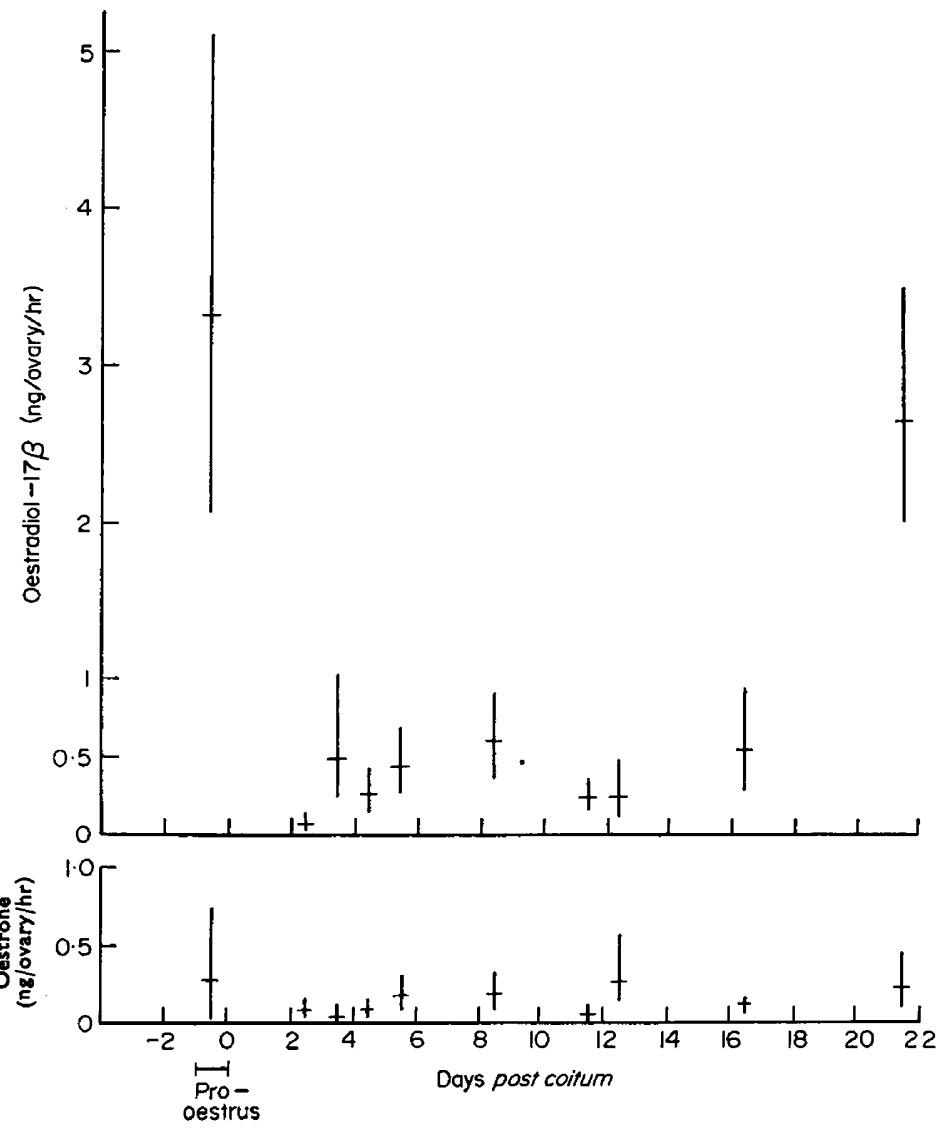

TExT-FIG. 1. Secretion rates of oestrogen into ovarian venous blood of rats. Vertical lines indicate $95 \%$ confidence limits of the estimated values.

Ovarian venous blood flow averaged $5.3 \mathrm{ml} /$ ovary $/ \mathrm{hr}$ at pro-oestrus and 4.6 and $7.9 \mathrm{ml} /$ ovary/hr on the $3 \mathrm{rd}$ and $22 \mathrm{nd}$ day post coitum. The estimated daily rate of increase of $0.15 \pm 0.025 \mathrm{ml} / \mathrm{ovary} / \mathrm{hr}$ in blood flow during pregnancy was highly significant $(P<0.001)$.

\section{DISCUSSION}

Estimates of total oestrogen secretion into the ovarian venous plasma have been reported by Hori, Ide \& Miyake (1968) for cycling rats, using the tetrazolium- 
reduction assay but with a pooled-standard procedure; by Yoshinaga, Hawkins \& Stocker (1969) for cycling and pregnant rats, using bioassay based on vaginal cytology; and by Shaikh \& Abraham (1969) for pseudopregnant rats using a radioimmunoassay in which the oestradiol-17 $\beta$ antiserum had only a small cross-reaction with oestrone. Yoshinaga et al. (1969) found a marked rise in total oestrogen secretion immediately before parturition to the level of that on the day of pro-oestrus. Their estimates of the rate of total oestrogen secretion (about $10 \mathrm{ng} / \mathrm{ovary} / \mathrm{hr}$ ) one day before parturition and at pro-oestrus were slightly higher than that found by Hori et al. (1968) for pro-oestrous rats (also total oestrogen) but were considerably higher than our estimates for oestradiol$17 \beta$ (Text-fig. 1).

Sample collection time $(30 \mathrm{~min})$ was the same in the present studies as in those of Yoshinaga et al. (1969), the sample volumes obtained were very similar and the rate of blood flow showed a similar rise during pregnancy. Since ovarian oestrone secretion is relatively low, the fact that Yoshinaga et al. (1969) determined total oestrogen secretion seems unlikely to explain why the actual values they found were considerably greater.

It is generally believed - the evidence has recently been reviewed by Rossi Cartoni \& Bignami (1969) - that blastocyst nidation and implantation in rats from the 5th day post coitum is due to the uterus passing from a progesteronedominated phase to one of oestrogen domination. The observed rise in ovarian oestradiol-1 $7 \beta$ secretion from the 3 rd to the 4 th day may constitute the beginning of this. In some experiments in the present study in which ovarian venous samples were collected during successive 4-hr periods from 10.00 to 22.00 hours on the 4th day post coitum, some differences in the secretion rate of oestradiol-17 $\beta$ were found. It is still, however, uncertain whether the increased ovarian oestradiol-17 $\beta$ secretion preceding blastocyst implantation may be described as a peak or a rise followed by a levelling out (both possibilities have been predicted on biological evidence; see review by Rossi Cartoni \& Bignami, 1969). For pseudopregnant rats, Shaikh \& Abraham (1969) found a rise in ovarian oestradiol-17 $\beta$ secretion early on the 4 th day, followed by a fall later that day.

It is known that, following implantation, oestrogen continues to be essential for the maintenance of gestation in rats and it is believed (Alloiteau \& Mayer, 1967) that it is involved with prolactin (hypophysial and placental) in support of corpus luteum function. It is of interest, therefore, to note that oestradiol-17 $\beta$ (and oestrone) secretion does continue from the 4th to the 17 th day post coitum, a period when considerable increase in CL volume and progesterone secretion occurs.

Alloiteau \& Mayer (1967) have concluded from biological evidence that at the end of pregnancy in rats, there is a greatly increased secretion of oestrogen (produced by the corpora lutea, not the placentae). This is supported by Csapo (1969) and his colleagues, who have shown that rats ovariectomized 2 days before term maintained live litters but failed to deliver them; oestrogen replacement therapy on the expected day of parturition resulted in normal delivery. It is concluded that the greatly increased ovarian oestradiol-17 $\beta$ secretion in the last 1 to 2 days of gestation, when progesterone secretion has fallen to low 
values, provides physiologically the high oestrogen levels required for normal delivery.

Since the oestradiol-17 $\beta$ secretion rate before parturition is so similar to that at pro-oestrus, it is probable that it is involved in the mechanism for LH release and ovulation post partum as for cycling rats (Ferin, Tempone, Zimmering \& Vande Wiele, 1969).

\section{ACKNOWLEDGMENT}

We thank Mr R. Parkin for assistance with the bioassay.

\section{REFERENCES}

Alloiteau, J. J. \& Mayer, G. (1967) Développement, maintien et régression du corps jaune. Archs Anat. microsc. Morph. exp. 56, Suppl. au no. 3-4, 189.

Brown, J. B. (1955) A chemical method for the determination of oestriol, oestrone and oestradiol in human urine. Biochem. 7. 60, 185.

Csapo, A. (1969) The four direct regulatory factors of myometrial function. In: Progesterone, its Regulatory Effect on the Myometrium, p. 13. Eds. G. E. W. Wolstenholme and J. Knight. Churchill, London.

Ferin, M., Tempone, A., Zimmering, P. E. \& Vande Wiele, R. L. (1969) Effect of antibodies to $17 \beta$-estradiol and progesterone on the estrous cycle of the rat. Endocrinolog, 85, 1070.

Finney, D. J. (1964) Statistical method in biological assay. Griffin, London.

Ganguly, J., Pope, G. S., Thompson, S. Y., Toothill, J., Edwards-Webe, J. D. \& Waynporth, H. B. (1971) Studies on metabolism of vitamin A. The effect of vitamin A status on the secretion rate of some steroids into the ovarian venous blood of pregnant rats. Biochem. F. 122, 235.

HORI, T., IDE, M. \& MrYAKE, T. (1968) Ovarian estrogen secretion during the estrous cycle and under the influence of exogenous gonadotropins in rats. Endocr. jap. 15, 215.

Martin, L. (1960) The use of 2-3-5-triphenyltetrazolium chloride in the biological assay of oestrogens. F. Endocr. 20, 187.

Martin, L. (1964) Further studies on the use of tetrazolium in the biological assay of oestrogens. $\mathcal{F}$. Endocr. 30, 21.

Rossi Cartoni, C. \& Bignami, G. (1969) Oestrogen-dependence of decidualization in some Myomorph rodents: basic endocrine mechanisms and their biological significance. Annali Istituto sup. Sanita, $5,107$.

Shaikh, A. A. \& ABraham, G. E. (1969) Measurement of estrogen surge during pseudopregnancy in rats by radioimmunoassay. Biol. Reprod. 1,378 .

Storry, J. E. \& TuckLey, B. (1967) Thin-layer chromatography of plasma lipids by single development. Lipids, 2, 501.

Yoshinaga, K., Hawkins, R. A. \& STocker, J. F. (1969) Estrogen secretion by the rat ovary in vivo during the estrous cycle and pregnancy. Endocrinology, 85, 103. 